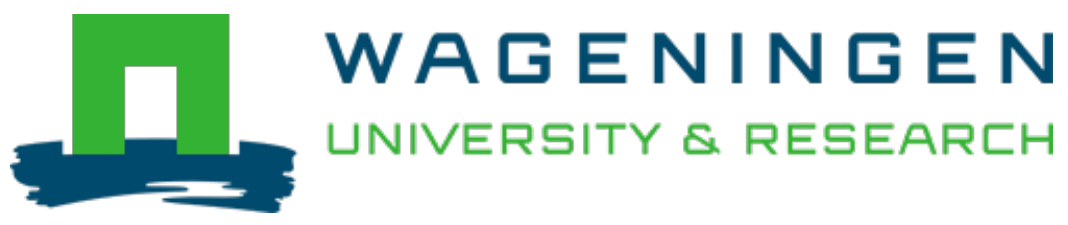

\title{
Traditional fermented products from Africa, Latin America and Asia
}

Yeasts in Food - Beneficial and Detrimental Aspects

Nout, M.J.R.

https://doi.org/10.1533/9781845698485.451

This publication is made publicly available in the institutional repository of Wageningen University and Research, under the terms of article $25 \mathrm{fa}$ of the Dutch Copyright Act, also known as the Amendment Taverne. This has been done with explicit consent by the author.

Article $25 \mathrm{fa}$ states that the author of a short scientific work funded either wholly or partially by Dutch public funds is entitled to make that work publicly available for no consideration following a reasonable period of time after the work was first published, provided that clear reference is made to the source of the first publication of the work.

This publication is distributed under The Association of Universities in the Netherlands (VSNU) 'Article $25 \mathrm{fa}$ implementation' project. In this project research outputs of researchers employed by Dutch Universities that comply with the legal requirements of Article $25 \mathrm{fa}$ of the Dutch Copyright Act are distributed online and free of cost or other barriers in institutional repositories. Research outputs are distributed six months after their first online publication in the original published version and with proper attribution to the source of the original publication.

You are permitted to download and use the publication for personal purposes. All rights remain with the author(s) and / or copyright owner(s) of this work. Any use of the publication or parts of it other than authorised under article $25 \mathrm{fa}$ of the Dutch Copyright act is prohibited. Wageningen University \& Research and the author(s) of this publication shall not be held responsible or liable for any damages resulting from your (re)use of this publication.

For questions regarding the public availability of this publication please contact openscience.library@wur.nl 


\title{
17 Traditional fermented products from Africa, Latin America and Asia
}

\author{
M.J. ROBERT NOUT
}

\subsection{Introduction}

Fermentation is regarded as one of the oldest-known methods of food processing and preservation. Fermented foods and beverages are obtained by the action of micro-organisms (bacteria, yeasts and mycelial fungi) and their enzymes. Traditional fermented foods, also referred to as indigenous fermented foods, are those popular products that are known since early history and that can be prepared in the household or cottage industry using relatively simple techniques and equipment. The world-wide diversity of traditional fermented foods, their preparation methods and safety aspects are the subject of several textbooks and encyclopedia [1, 7, 61]. This chapter will deal with some of the documented foods of Africa, Latin America and Asia. As other chapters deal specifically with shoyu (Chapter 15), cocoa (Chapter 16), coffee (Chapter 16), wine (Chapter 14) and kefyr (Chapter 8), this chapter will not include those products.

Yeasts occur in a wide range of fermented foods, made from ingredients of plant as well as animal origin. When yeasts are present as an abundant group of organisms, they usually have a significant impact on food quality parameters such as taste, texture, odour, as well as nutritive value. There are many products however, in which yeasts take part in the fermentation in small numbers next to the presence of bacteria or mycelial fungi. Such mixed food fermentations sometimes are characterized by synergistic and very stable communities of e. g., yeasts and lactic acid bacteria (LAB), or yeasts and amylolytic mycelial fungi that depend on each other for nutrient supply [38]. On the other hand, the presence of some yeasts in fermented foods can result in undesirable reactions and can thus be considered as spoilage. The present chapter will deal with the occurrence of yeasts (biodiversity), their beneficial effects in fermented foods, as well as some cases of negative effects. Future prospects for development and industrialization will be discussed.

\subsection{Yeast biodiversity related to specific fermented products}

A large variety of yeasts can be found as functional flora in traditional fermented foods world-wide. Table 17.2-1 summarizes some major catogories of fermented foods and beverages. Some representative examples will be discussed in more detail.

In all continents, yeasts play a predominant role in the preparation of alcoholic beverages made from cereals or sugary juices. Likewise, fermented doughs and batters are encoun- 
Table 17.2-1 Major categories of traditional fermented foods involving yeasts

\begin{tabular}{|c|c|c|c|c|}
\hline Continent & $\begin{array}{l}\text { Alcoholic } \\
\text { beverages }\end{array}$ & $\begin{array}{l}\text { Starters for } \\
\text { alcoholic } \\
\text { fermentation }\end{array}$ & $\begin{array}{l}\text { Doughs and } \\
\text { Batters }\end{array}$ & Miscellaneous \\
\hline Africa & $\begin{array}{l}\text { made from maize, } \\
\text { sorghum or } \\
\text { millets, using } \\
\text { malt for brewing: } \\
\text { busaa [36, 37], } \\
\text { pito [56]), ting [34]. } \\
\text { palmwine [65] }\end{array}$ & $\begin{array}{l}\text { natural fermenta- } \\
\text { tion (no starters } \\
\text { added), or yeast } \\
\text { grown on inocu- } \\
\text { lation belt [56] }\end{array}$ & $\begin{array}{l}\text { made from cereals } \\
\text { (maize, sorghum, } \\
\text { millets): kenkey } \\
\text { [50], kisra [42], } \\
\text { mawè [23], or root- } \\
\text { crops (cassava): } \\
\text { agbelima [2], fufu } \\
\text { [48], lafun [42], } \\
\text { mostly fermented } \\
\text { before cooking. }\end{array}$ & $\begin{array}{l}\text { fermented milk } \\
\text { products: amasi } \\
\text { [14], m'bannick [35], } \\
\text { fermented vegeta- } \\
\text { bles: kawal [18], } \\
\text { non-or low-alcohol- } \\
\text { ic cereal beverages: } \\
\text { togwa [42] }\end{array}$ \\
\hline $\begin{array}{l}\text { Latin } \\
\text { America }\end{array}$ & $\begin{array}{l}\text { made from sugary } \\
\text { juices: aguardente } \\
{[33], \text { pulque }[8,60] \text {, }} \\
\text { toddy [30] found } \\
\text { world-wide }\end{array}$ & $\begin{array}{l}\text { natural fermen- } \\
\text { tation }\end{array}$ & $\begin{array}{l}\text { made from maize, } \\
\text { cooked before } \\
\text { fermentation: } \\
\text { pozol }[45]\end{array}$ & $\begin{array}{l}\text { non-or low-alcohol- } \\
\text { ic beverages: sug- } \\
\text { ary kefyr }[38] \text {, } \\
\text { tibicos }[3,8] \text {. }\end{array}$ \\
\hline Asia & $\begin{array}{l}\text { made from rice, } \\
\text { using amylolytic } \\
\text { starters for brew- } \\
\text { ing: beers or } \\
\text { wines: brem bali } \\
\text { [39], chongju [29], } \\
\text { ou [39], sake [29, } \\
\text { 37], samsu [30], } \\
\text { sato [39], shaohing } \\
\text { [39], takju [29], tapuy } \\
\text { [39], yakju [39], } \\
\text { or pasty snacks: } \\
\text { khaomak [29], } \\
\text { peuyeum (= tape } \\
\text { ketella) [29, 37], } \\
\text { tapai pulut [29], tape } \\
\text { ketan [9]. }\end{array}$ & $\begin{array}{l}\text { yeasts present in } \\
\text { mixed fungal } \\
\text { amylolytic starters } \\
{[42] \text { : bubod }} \\
{[52,53], \text { koji [39], }} \\
\text { murcha [63], nuruk } \\
\text { [29], ragi-tape [37]. }\end{array}$ & $\begin{array}{l}\text { made mostly } \\
\text { from rice and } \\
\text { leguminous seed } \\
\text { flour (dal), fer- } \\
\text { mented before } \\
\text { steaming (some } \\
\text { other cereals } \\
\text { such as millets } \\
\text { may be used): } \\
\text { dhokla [29], dosa } \\
\text { [5], idli [43, 58, 66], } \\
\text { jalebies [5], nan } \\
\text { [39], phool waries } \\
\text { [5], punjabi waries } \\
\text { [5]. }\end{array}$ & $\begin{array}{l}\text { fermented milk } \\
\text { products: kumiss } \\
\text { [32], fermented } \\
\text { mass of legumi- } \\
\text { nous seeds (mainly } \\
\text { soybeans): } \\
\text { hamanatto [37], } \\
\text { kinema [55], miso } \\
\text { [37], tempe [41, 44], } \\
\text { non-or low-alcohol- } \\
\text { ic beverages: kom- } \\
\text { bucha }[37,49,64] \text {. }\end{array}$ \\
\hline
\end{tabular}

tered in all continents. These doughs and batters may be leavened (i. e., have a spongy texture due to gas produced) or not, but in most cases they are cooked or steamed prior to consumption as a staple food providing starch, energy and some protein. Unlike alcoholic beverages, doughs and batters are fermented by a majority population of bacteria usually dominated by lactic acid bacteria. Nevertheless, yeasts are present in significant numbers and contribute to flavour, texture and nutritive value of the products. 


\subsubsection{Alcoholic beverages}

A distinction will be made on the basis of principles of generating fermentable sugars. Plant or fruit juices containing sufficient levels of glucose or sucrose are the easiest to ferment. They simply need to be inoculated, naturally from the environment or using an enrichment starter or pure culture. Pulque is an example of such a fermentation.

On the other hand, when cereals are used as ingredients, endosperm starch needs to be converted into fermentable sugars (maltose and glucose). This can be achieved using added amylolytic enzymes, sources of which are germinated (sprouted) cereal grains or mixed fungal amylolytic starters. In African beermaking, germinated sorghum and millets are commonly used in brewing; the preparation of pito beer from sorghum is a representative example. In most Asian countries, amylolytic starters are used in the form of starchy tablets containing mixed cultures of starch degrading moulds and yeasts. Such starters are used for the manufacture of beers, wines and pasty snacks from various kinds of rice, sorghum, and cassava. The preparation of takju in Korea, using a starter called nuruk is a representative example.

Mexican pulque (Figure 17.2-1) is made from Agave juice (Agave atrovirens or A. americana). Essential micro-organisms in the fermentation are Lactobacillus plantarum, a heterofermentative Leuconostoc, Zymomonas mobilis and Saccharomyces cerevisiae. Other yeasts include, Candida parapsilosis, C. rugosa, C. rugopelliculosa, Debaryomyces carsonii, Pichia guilliermondii, P. membranifaciens and Torulaspora delbrueckii [28]. Although $S$. cerevisiae appears to be the major producer of ethanol, it is Z. mobilis that transforms $45 \%$ of the glucose to ethanol (4-6\% v/v in final product) and carbon dioxide [60].

Pito beer (Figure 17.2-2) from Ghana is obtained by mixed activities of lactic acid bacteria and yeasts. It is a yellow to brown coloured sorghum beer that is obtained from previously germinated sorghum which is extracted, boiled and inoculated. Depending on the type of pito, the inoculation is achieved by immersing a woven "inoculation belt" (Figure 17.2-3) which allows entrapment of microbial cells. Other inoculation methods include back-slop-

Fig. 17.2-1 Manufacture of pulque (Mexico)

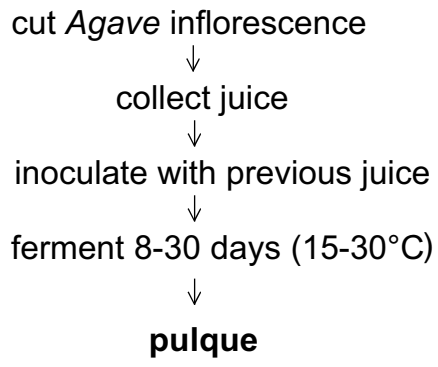

(white viscous, sour-alcoholic beverage) 


\section{Fig. 17.2-2 Manufacture of pito} (Ghana)

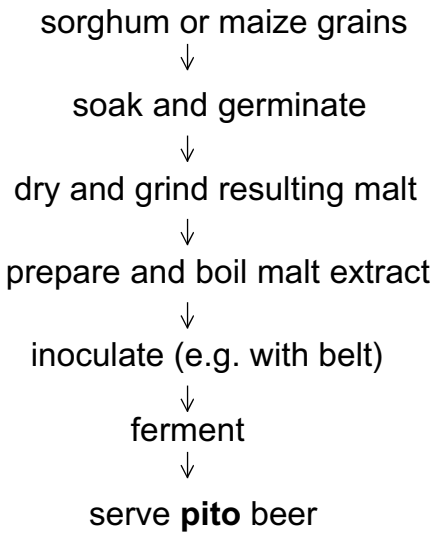

ping (addition of previous beer), or adding dried scum (foam) of previous beer [56]. After fermentation it typically contains $1.5-3.5 \% \mathrm{v} / \mathrm{v}$ ethanol and $0.7-1.0 \% \mathrm{w} / \mathrm{w}$ lactic acid and a corresponding $\mathrm{pH}$ of about 3.5 .

Takju (Figure 17.2-4) is a Korean rice beer, which can also be prepared from other cereals. The nuruk starter is made by solid-state fermentation of wheat flour with Aspergillus usamii. After approximately 2 months fermentation, nuruk also contains Rhizopus, Aspergillus niger and yeasts such as Debaryomyces hansenii, D. occidentalis, Pichia anomala, P. fabianii and Saccharomycopsis fibuligera. Nuruk contains fungal amylolytic enzymes to saccharify starch (brewing), as well as the yeasts needed for alcoholic fermentation. Takju is a turbid beer with suspended insoluble solids and living yeasts, containing 7-10\% ethanol, approx. $1 \%$ titratable acidity and has $\mathrm{pH} 4$ after 3 days fermentation [29, 39].

\subsubsection{Fermented doughs and batters}

In Africa, fermented doughs form the basis for a variety of staple foods. These doughs are first fermented, then cooked.

Mawè, an uncooked fermented maize dough from Bénin, is not consumed as such but it is used as an ingredient for the preparation of a wide variety of beverages, cooked and fried meals and snacks. Its fermentation (Figure 17.2-5) is dominated by heterofermentative lactic acid bacteria (>9 Log CFU/g) but a minority of yeasts (7-8 Log CFU/g) are important for the correct taste [23]. 
Fig. 17.2-3 Inoculation belt for pito fermentation

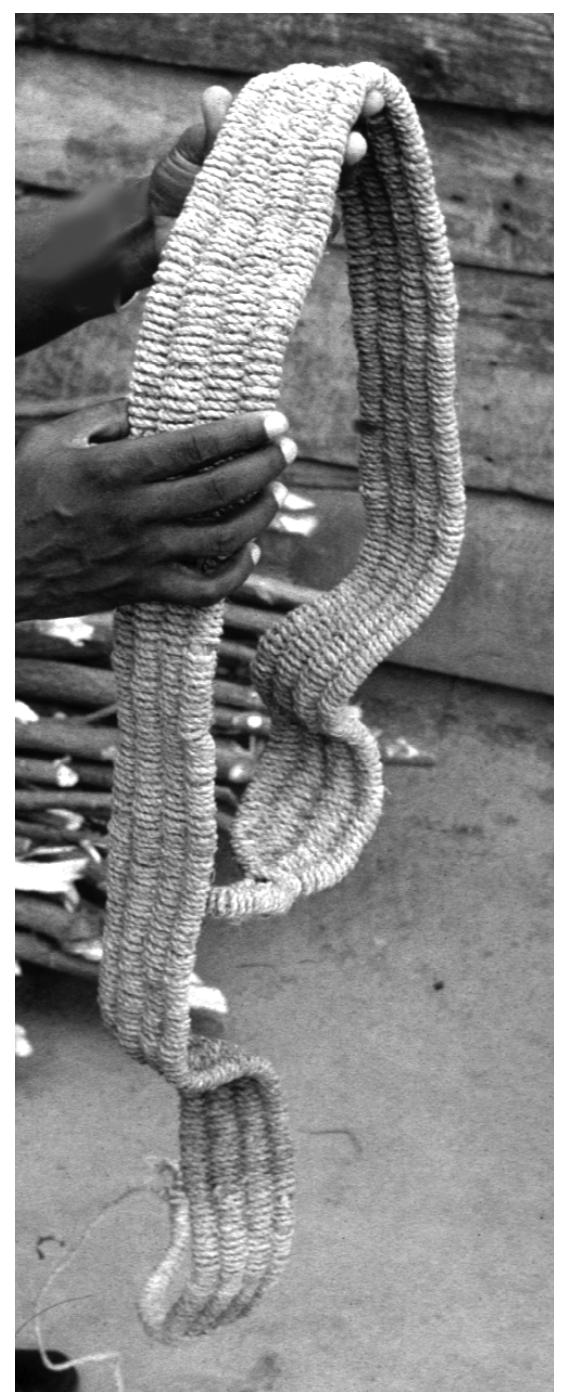




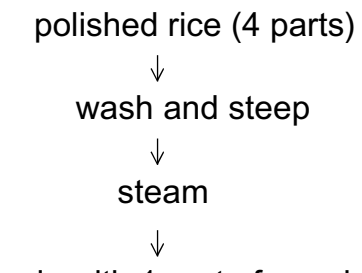

mix with 1 part of powdered nuruk and 10 parts of water in an earthen jar<smiles>[AlH]</smiles>

ferment for 2-3 days<smiles>[AlH][AlH2]</smiles>

sieve

$\downarrow$

serve takju beer
Fig. 17.2-4 Manufacture of takju (Korea)

Ghanaian Kenkey, a fermented and cooked stiff maize dough is fermented by mixed lactic acid bacteria and yeasts. Although yeasts (Issatchenkia orientalis and $S$. cerevisiae) are a minority with about 6-7 Log CFU/g compared to the LAB, they contribute to the taste and odour of kenkey [17, 42].

Nigerian Fufu is a product obtained by submerged cassava fermentation [48]. Yeasts are present in relatively high numbers ( $8 \mathrm{Log} \mathrm{CFU} / \mathrm{g}$ ) and comprise predominantly Issatchenkia orientalis, Candida tropicalis and Zygosaccharomyces bailii. These yeasts co-exist with lactic acid bacteria such as Lactobacillus plantarum. The growth of the latter was reported to be enhanced in the presence of Issatchenkia orientalis.

In Mexico, a typical alkaline maize dough (nixtamal) is fermented after having been cooked. Mexican pozol (Figure 17.2-6) is a refreshing beverage prepared from fermented nixtamal, which is a dough made from maize cooked in alkali. In this fermentation, which takes about $12-60 \mathrm{~h}$, yeasts are a minority (2-7 Log CFU/g), and the fermented dough contains a majority of lactic acid bacteria resulting in $\mathrm{pH} 4.7-5.7$ and $0.35-0.75 \%$ titratable acidity. It was reported that $50 \%$ of the yeasts isolated from this product can hydrolyze starch [8].

In Asia, leavened batters of rice and leguminous flour are obtained by fermentation. Subsequently they are steamed. Idli is popular throughout India and Sri Lanka because of its typ- 


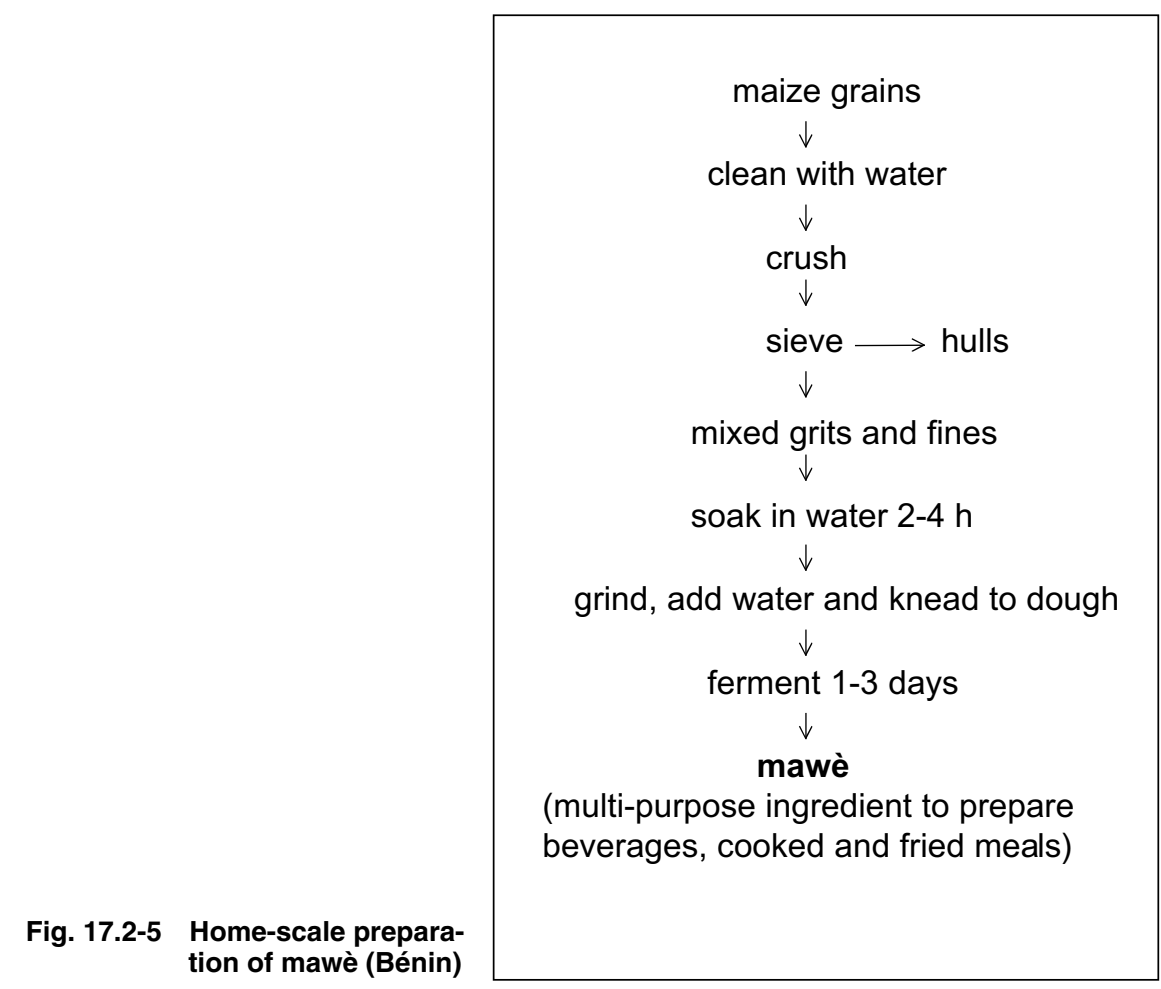

ical sour flavour and spongy texture, nutritional quality and improved digestibility. It is fed to infants as a weaning food, and as a main dish in diets in hospitals [43].

The main ingredients used in the traditional preparation of idli (Figure 17.2-7) are white polished rice (Oryza sativa L.) and black gram (Phaseolus mungo L.) dal, which are washed, soaked separately in water at room temperature for 5-10 hours before grinding in a stone mortar or other grinders. While rice is coarsely ground, the dal is ground to a fine smooth paste. The rice and dal slurries are mixed and stirred to form a thick batter. Salt is added to taste. The batter, put in a closed container, is kept at a warm place to ferment overnight or longer. The fermentation period must allow a definite leavening of the batter and development of a pleasant acid flavour. The fermented batter is poured in small cups or in a special idli pan having cups $(8-10 \mathrm{~cm}$ diam), and steamed until the starch is gelatinized and the idli cakes are soft and spongy. The fermented batter is consumed the same day and there is no effort to preserve it.

Idli is a natural fermented food; no inoculum is added generally for fermentation. This is because the essential microorganisms have been found to be naturally present in the ingre- 


\title{
Fig. 17.2-6 Preparatio and use of pozol (Mexico)
}

\author{
maize grains \\ cook in lime water \\ (about 1 hour)<smiles>[AlH2]</smiles>

dients. When the product is made daily, it is often the practice of adding a bit of freshly fermented batter ("backslop") to the newly ground one. In addition to lactic acid bacteria (Leuconostoc mesenteroides, Enterococcus faecalis, Lactobacillus fermentum and Pediococcus cerevisiae) the slightly acid environment favours the growth and activity of yeasts, mainly Saccharomyces cerevisiae, Debaromyoces hansenii var. hansenii, Pichia anomala, Candida saitoana and Trichosporon cutaneum var. cutaneum.

The major functions of the fermentation include the leavening of the batter and the improvement of taste and nutritional value of idli. Leuconostoc mesenteroides is the main species responsible for the production of $\mathrm{CO}_{2}$ which results in about 2-3 times increase in the original volume of batter [58].

\subsubsection{Some other products}

In western Sudan, kawal, sigda and furundu are fermented products made by solid-state fermentation from plant leaves and seeds [18]. The fermentation of kawal is dominated by $B a$ - 


\section{Fig. 17.2-7 Preparation of idli} (India, Sri Lanka)

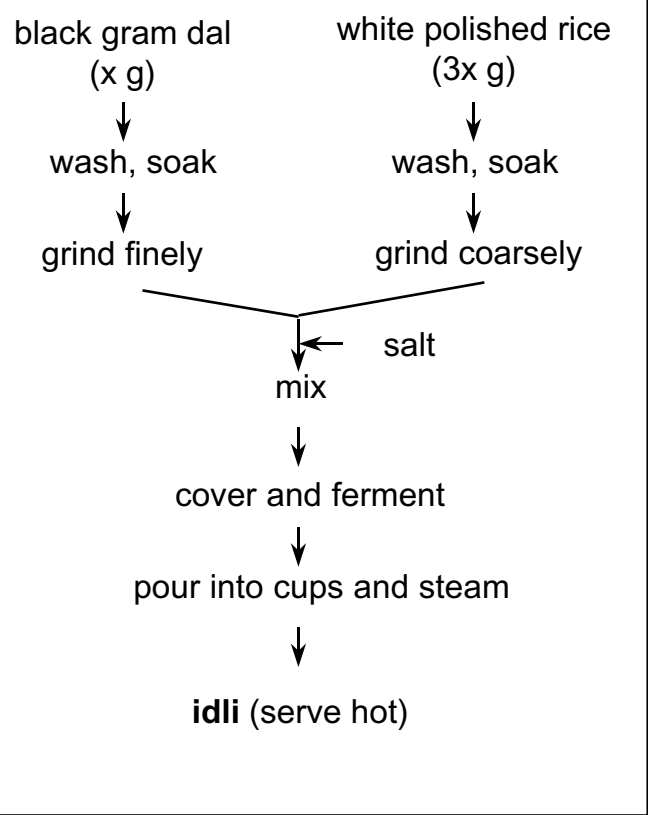

cillus subtilis, Lactobacillus plantarum, Propionibacterium sp. and Staphylococcus sciuri, and two yeasts Issatchenkia orientalis and Saccharomyces sp. During later stages of the fermentation, Debaryomyces and Candida spp. are detected in low numbers. The role of the yeasts is to degrade starch into fermentable sugars in the early stages of fermentation, and in later stages they consume lactic acid. It is not clear whether amylolytic yeasts are to be considered desirable or not for this type of fermentation.

Mexican tibicos, also called tibi grains, and probably similar to sugary kefyr, are microbiogleae consisting of dextran with embedded bacteria and yeasts (Dekkera anomala, Pichia guilliermondii, P. membranifaciens var. membranifaciens, Cryptococcus albidus, Rhodotorula mucilaginosa var. mucilaginosa and Saccharomyces cerevisiae) that live in symbiosis. Tibicos are used to prepare a kind of soft drink from sugar cane juice, containing approximately $3 \%$ sugar, $0.6 \%$ lactic acid and traces of alcohol and acetic acid, after 5 days of fermentation [51].

Kinema from Nepal and north-east India [55] is one of several "alkaline fermented foods" made from protein-rich seeds (e. g., soy beans) with a predominant Bacillus subtilis fermentation. During the fermentation a sticky mass is formed of $\mathrm{pH} 8.5$ that is consumed as a fla- 
vouring condiment. Yeasts, particularly Candida parapsilosis are a minority $(<5.2 \log$ $\mathrm{CFU} / \mathrm{g}$ ) in the microflora and their contribution to the product quality is still uncertain.

Tempe from Indonesia is a fungal solid-state fermented cake-like product, usually made from soy beans [41]. It's principal functional micro-organisms are Rhizopus and Mucor spp. but various bacteria and yeasts may be present, in relatively high (4-8 Log CFU/g) numbers. The predominant yeasts include Debaryomyces, Rhodotorula, Candida, Pichia and Cryptococcus spp. (VAN LAARHOVEN, unpubl. observ.).

Kombucha from Central and East Asia is a beverage obtained by fermentation of sweetened boiled tea with a mixed culture of yeasts and acetic acid bacteria [7].

\subsection{Beneficial aspects of yeasts in fermentations}

Yeasts can have several beneficial effects:

Functional effects, by the production of alcohol, gas, flavour and taste, as well as a contribution to food preservation by scavenging of sugars and other compounds that could otherwise serve as assimilable carbon sources for spoilage-causing micro-organisms. The production of alcohol improves the aroma of the product. In addition, alcohol at a certain concentration makes the substrate unsuitable for spoilage-causing microorganisms. This effect is increased in the presence of organic acids produced by bacteria. However, this preservative effect is not always a guarantee for long shelf-life as was observed in African beers such as Burukutu and Pito made from maize and sorghum [54]. These underwent spoilage within $72 \mathrm{~h}$ after the end of fermentation. The spoilage was associated with a decline of the yeast flora, and a concomitant increase and dominance of acetic acid bacteria including Acetobacter aceti, A. pasteurianus and A. hansenii.

The typical attractive volatiles produced by yeasts in fermentations of cereals such as maize include ethanol, propanol, 2-methyl-1-propanol, 3-methyl-1-butanol (isoamylalcohol), 2,3 butanediol, acetaldehyde, acetoin, diacetyl (2,3 butanedione), acetic acid, and ethyl acetate $[10,17,40]$. In agbelima, a fermented cassava dough [2], the volatile aroma was also attributed to the yeasts present, which produce various alcohols as well as ethylacetate and acetoin. In particular, the ability to assimilate or ferment the available carbohydrates, determines the evolution of attractive odours. These are produced almost exclusively by fermentation [40]. In Table 17.3-1, the ability to ferment glucose is mentioned for all relevant yeast species.

A study of palm wine volatile aroma [65] pointed out that Saccharomyces spp. were the major responsible organisms for the attractive odour. About 17 esters, 4 alcohols, 4 terpenes and 2 hydrocarbons were detected in the headspace volatiles.

Nutritional improvement due to increasing the digestibility of foods by the degradation of anti-nutritional factors such as phytate, and by the synthesis of nutrients such as vitamins. For example, S. cerevisiae and Issatchenkia orientalis occurring in African sorghum 
Tab. 17.3-1 Yeast genera and species predominating in fermented foods

\begin{tabular}{|c|c|c|c|c|}
\hline Genus & Species & $\begin{array}{l}\text { Synonyms } \\
\text { reported in } \\
\text { literature } \\
\text { sources }\end{array}$ & $\begin{array}{l}\text { Fermen- } \\
\text { tation of } \\
\text { glucose }\end{array}$ & $\begin{array}{l}\text { Traditional } \\
\text { Fermented Foods }\end{array}$ \\
\hline Candida & fennica & $\begin{array}{l}\text { Trichosporon } \\
\text { fennicum }\end{array}$ & + & tapuy \\
\hline Candida & glabrata & & + & idli, mawè \\
\hline Candida & inconspicua & $\begin{array}{l}\text { Torulopsis } \\
\text { inconspicua }\end{array}$ & - & yakju \\
\hline Candida & $\begin{array}{l}\text { intermedia var. } \\
\text { intermedia }\end{array}$ & $\begin{array}{l}\text { Candida } \\
\text { intermedia }\end{array}$ & + & tempe \\
\hline Candida & maltosa & & + & tempe \\
\hline Candida & $\begin{array}{l}\text { parapsilosis var. } \\
\text { parapsilosis }\end{array}$ & $\begin{array}{l}\text { Candida } \\
\text { parapsilosis }\end{array}$ & + & $\begin{array}{l}\text { bubod, kinema, } \\
\text { pulque, tapuy }\end{array}$ \\
\hline Candida & rugopelliculosa & & + & pulque \\
\hline Candida & $\begin{array}{l}\text { rugosa var. } \\
\text { rugosa }\end{array}$ & Candida rugosa & - & pulque \\
\hline Candida & saitoana & Torulopsis candida & w & $\begin{array}{l}\text { bubod, idli, dosa, } \\
\text { dhokla }\end{array}$ \\
\hline Candida & sake & & v & $\begin{array}{l}\text { aguardente, idli, } \\
\text { tempe }\end{array}$ \\
\hline Candida & sake & Torulopsis sake & $\mathrm{v}$ & yakju \\
\hline Candida & spp. & & & $\begin{array}{l}\text { brem bali, fufu, } \\
\text { kombucha } \\
\text { (= teekvass), lafun, } \\
\text { ou, pito, pozol, } \\
\text { sato, toddy }\end{array}$ \\
\hline Candida & stellata & & w & kombucha \\
\hline Candida & $\begin{array}{l}\text { tropicalis var. } \\
\text { tropicalis }\end{array}$ & & + & $\begin{array}{l}\text { agbelima, bubod, } \\
\text { fufu, idli, pito }\end{array}$ \\
\hline Candida & versatilis & $\begin{array}{l}\text { Torulopsis } \\
\text { versatilis }\end{array}$ & w & $\begin{array}{l}\text { hamanatto, idli, } \\
\text { kombucha, miso }\end{array}$ \\
\hline Clavispora & Iusitaniae & Candida Iusitaniae & + & amasi, tempe \\
\hline Cryptococcus & $\begin{array}{l}\text { albidus var. } \\
\text { albidus }\end{array}$ & $\begin{array}{l}\text { Cryptococcus } \\
\text { albidus }\end{array}$ & - & tibicos \\
\hline Cryptococcus & humicola & & - & tempe \\
\hline Debaryomyces & carsonii & Pichia carsonii & - & pulque \\
\hline Debaryomyces & $\begin{array}{l}\text { hansenii var. } \\
\text { hansenii }\end{array}$ & Candida famata & $v$ & nuruk, tibicos \\
\hline
\end{tabular}


Tab. 17.3-1 Continued

\begin{tabular}{|c|c|c|c|c|}
\hline Genus & Species & $\begin{array}{l}\text { Synonyms } \\
\text { reported in } \\
\text { literature } \\
\text { sources }\end{array}$ & $\begin{array}{l}\text { Fermen- } \\
\text { tation of } \\
\text { glucose }\end{array}$ & $\begin{array}{l}\text { Traditional } \\
\text { Fermented Foods }\end{array}$ \\
\hline Debaryomyces & $\begin{array}{l}\text { hansenii var. } \\
\text { hansenii }\end{array}$ & & $\mathrm{v}$ & idli, tapuy, tempe \\
\hline Debaryomyces & $\begin{array}{l}\text { occidentalis var. } \\
\text { occidentalis }\end{array}$ & & + & tempe \\
\hline Debaryomyces & $\begin{array}{l}\text { occidentalis var. } \\
\text { occidentalis }\end{array}$ & $\begin{array}{l}\text { Schwanniomyces } \\
\text { occidentalis }\end{array}$ & + & nuruk \\
\hline Debaryomyces & $\begin{array}{l}\text { polymorphus var. } \\
\text { polymorphus }\end{array}$ & Pichia polymorpha & v & yakju \\
\hline Dekkera & bruxellensis & $\begin{array}{l}\text { Brettanomyces } \\
\text { bruxellensis }\end{array}$ & w & kombucha \\
\hline Dekkera & anomala & $\begin{array}{l}\text { Brettanomyces } \\
\text { claussenii }\end{array}$ & + & tibicos \\
\hline Hanseniaspora & uvarum & $\begin{array}{l}\text { Kloeckera } \\
\text { apiculata }\end{array}$ & + & pito, sugary kefir \\
\hline Issatchenkia & orientalis & Candida krusei & + & $\begin{array}{l}\text { busaa, fufu, idli, } \\
\text { kawal, kenkey, } \\
\text { kisra, mawè, } \\
\text { phool waries, } \\
\text { punjabi waries, } \\
\text { togwa }\end{array}$ \\
\hline Kluyveromyces & africanus & & + & pito \\
\hline Kluyveromyces & $\begin{array}{l}\text { marxianus var. } \\
\text { marxianus }\end{array}$ & Candida kefyr & + & kumiss, mawè \\
\hline Kluyveromyces & $\begin{array}{l}\text { marxianus var. } \\
\text { marxianus }\end{array}$ & $\begin{array}{l}\text { Candida } \\
\text { pseudotropicalis }\end{array}$ & + & m'bannick \\
\hline Kluyveromyces & $\begin{array}{l}\text { marxianus var. } \\
\text { marxianus }\end{array}$ & $\begin{array}{l}\text { Kluyveromyces } \\
\text { fragilis }\end{array}$ & + & kumiss \\
\hline Kluyveromyces & $\begin{array}{l}\text { marxianus var. } \\
\text { marxianus }\end{array}$ & & + & $\begin{array}{l}\text { aguardente, } \\
\text { kumiss, pulque }\end{array}$ \\
\hline Lodderomyces & elongisporus & & + & tempe \\
\hline Pichia & anomala & & + & $\begin{array}{l}\text { bubod, fufu, } \\
\text { murcha }\end{array}$ \\
\hline Pichia & anomala & Candida javanica & + & $\begin{array}{l}\text { amylolytic starters, } \\
\text { idli, kombucha, } \\
\text { murcha }\end{array}$ \\
\hline
\end{tabular}


Tab. 17.3-1 Continued

\begin{tabular}{|c|c|c|c|c|}
\hline Genus & Species & $\begin{array}{l}\text { Synonyms } \\
\text { reported in } \\
\text { literature } \\
\text { sources }\end{array}$ & $\begin{array}{l}\text { Fermen- } \\
\text { tation of } \\
\text { glucose }\end{array}$ & $\begin{array}{l}\text { Traditional } \\
\text { Fermented Foods }\end{array}$ \\
\hline Pichia & anomala & $\begin{array}{l}\text { Hansenula } \\
\text { anomala }\end{array}$ & + & $\begin{array}{l}\text { bubod, idli, jale- } \\
\text { bies, koji, murcha, } \\
\text { nuruk, pito, tape } \\
\text { ketan, saké, yakju }\end{array}$ \\
\hline Pichia & fabianii & Candida fabianii & + & nuruk \\
\hline Pichia & fabiani & Hansenula fabiani & + & tempe \\
\hline Pichia & $\begin{array}{l}\text { fermentans var. } \\
\text { fermentans }\end{array}$ & Candida lambica & + & sugary kefir \\
\hline Pichia & fluxuum & $\begin{array}{l}\text { Candida } \\
\text { mycoderma }\end{array}$ & w & ting \\
\hline Pichia & guilliermondii & $\begin{array}{l}\text { Candida } \\
\text { guilliermondii }\end{array}$ & w & $\begin{array}{l}\text { bubod, pulque, tibi- } \\
\text { cos }\end{array}$ \\
\hline Pichia & $\begin{array}{l}\text { membranifaciens } \\
\text { var. membrani- } \\
\text { faciens }\end{array}$ & Candida valida & w & sugary kefir, tibicos \\
\hline Pichia & $\begin{array}{l}\text { membranifaciens } \\
\text { var. membranifa- } \\
\text { ciens }\end{array}$ & $\begin{array}{l}\text { Pichia } \\
\text { membranaefaciens }\end{array}$ & w & pulque, ting \\
\hline Pichia & pini & & $\mathrm{v}$ & tempe \\
\hline Pichia & spp & & + & $\begin{array}{l}\text { khaomak, tapai pu- } \\
\text { lut }\end{array}$ \\
\hline Pichia & subpelliculosa & $\begin{array}{l}\text { Hansenula } \\
\text { subpelliculosa }\end{array}$ & + & yakju \\
\hline Rhodotorula & $\begin{array}{l}\text { glutinis var. } \\
\text { glutinis }\end{array}$ & & - & tapuy \\
\hline Rhodotorula & minuta var. minuta & & - & tempe \\
\hline Rhodotorula & $\begin{array}{l}\text { mucilaginosa var. } \\
\text { mucilaginosa }\end{array}$ & & - & tempe \\
\hline Rhodotorula & $\begin{array}{l}\text { mucilaginosa var. } \\
\text { mucilaginosa }\end{array}$ & Rhodotorula rubra & - & tibicos, ting \\
\hline
\end{tabular}


Tab. 17.3-1 Continued

\begin{tabular}{|c|c|c|c|c|}
\hline Genus & Species & $\begin{array}{l}\text { Synonyms } \\
\text { reported in } \\
\text { literature } \\
\text { sources }\end{array}$ & $\begin{array}{l}\text { Fermen- } \\
\text { tation of } \\
\text { glucose }\end{array}$ & $\begin{array}{l}\text { Traditional } \\
\text { Fermented Foods }\end{array}$ \\
\hline Saccharomyces & $\begin{array}{l}\text { cerevisiae var. } \\
\text { cerevisiae }\end{array}$ & & + & $\begin{array}{l}\text { aguardente, amasi, } \\
\text { amylolytic starters, } \\
\text { bubod, busaa, } \\
\text { chongju, fufu, idli, } \\
\text { jalebies, kenkey, } \\
\text { mawè, nan, palm } \\
\text { wine, pito, pulque, } \\
\text { punjabi waries, } \\
\text { saké, shaohing, } \\
\text { sugary kefir, takju, } \\
\text { tibicos, ting, yakju }\end{array}$ \\
\hline Saccharomyces & $\begin{array}{l}\text { cerevisiae var. } \\
\text { cerevisiae }\end{array}$ & $\begin{array}{l}\text { Saccharomyces } \\
\text { chevalieri }\end{array}$ & + & palm wine \\
\hline Saccharomyces & dairenensis & & + & amasi, tempe \\
\hline Saccharomyces & bayanus & $\begin{array}{l}\text { Saccharomyces } \\
\text { globosus }\end{array}$ & + & kumiss \\
\hline Saccharomyces & exiguus & Torulopsis holmii & + & idli \\
\hline Saccharomyces & kluyveri & & + & nan \\
\hline Saccharomyces & spp & & + & $\begin{array}{l}\text { brem bali, kawal, } \\
\text { khaomak, kom- } \\
\text { bucha (= teek- } \\
\text { vass), m'bannick, } \\
\text { ou, pito, sato, toddy }\end{array}$ \\
\hline Saccharomyces & unisporus & & + & bubod, kumiss \\
\hline Saccharomycodes & $\begin{array}{l}\text { ludwigii var. } \\
\text { ludwigii }\end{array}$ & & + & kombucha \\
\hline Saccharomycopsis & fibuligera & Candida lactosa & w & samsu \\
\hline Saccharomycopsis & fibuligera & $\begin{array}{l}\text { Endomycopsis } \\
\text { fibuliger }\end{array}$ & w & $\begin{array}{l}\text { bubod, murcha, nu- } \\
\text { ruk, peuyeum } \\
\text { (= tape ketella), } \\
\text { ragi-tape, tapai pu- } \\
\text { lut, tapuy }\end{array}$ \\
\hline Saturnispora & saitoi & Pichia saitoi & + & fufu \\
\hline $\begin{array}{l}\text { Schizosaccharo- } \\
\text { myces }\end{array}$ & $\begin{array}{l}\text { pombe var. } \\
\text { pombe }\end{array}$ & & + & kombucha, pito \\
\hline $\begin{array}{l}\text { Schizosaccharo- } \\
\text { myces }\end{array}$ & spp & & + & toddy \\
\hline
\end{tabular}


Tab. 17.3-1 Continued

\begin{tabular}{|c|c|c|c|c|}
\hline Genus & Species & $\begin{array}{l}\text { Synonyms } \\
\text { reported in } \\
\text { literature } \\
\text { sources }\end{array}$ & $\begin{array}{l}\text { Fermen- } \\
\text { tation of } \\
\text { glucose }\end{array}$ & $\begin{array}{l}\text { Traditional } \\
\text { Fermented Foods }\end{array}$ \\
\hline Torulaspora & delbrueckii & & + & kombucha, pito \\
\hline Torulaspora & delbrueckii & Candida colliculosa & + & amasi, pulque \\
\hline Torulaspora & pretoriensis & & + & sugary kefir \\
\hline Trichosporon & $\begin{array}{l}\text { cutaneum var. } \\
\text { cutaneum }\end{array}$ & $\begin{array}{l}\text { Trichosporon } \\
\text { beigelii }\end{array}$ & - & idli, tempe \\
\hline Trichosporon & $\begin{array}{l}\text { cutaneum var. } \\
\text { cutaneum }\end{array}$ & & - & pozol \\
\hline Trichosporon & pullulans & & - & idli \\
\hline Yarrowia & lipolytica & & - & tempe \\
\hline $\begin{array}{l}\text { Zygosaccha- } \\
\text { romyces }\end{array}$ & bailii var. bailii & $\begin{array}{l}\text { Zygosaccha- } \\
\text { romyces bailii }\end{array}$ & + & fufu, kombucha \\
\hline $\begin{array}{l}\text { Zygosaccha- } \\
\text { romyces }\end{array}$ & florentinus & & + & sugary kefir \\
\hline $\begin{array}{l}\text { Zygosaccha- } \\
\text { romyces }\end{array}$ & rouxii & & w & hamanatto, miso \\
\hline $\begin{array}{l}\text { Zygosaccha- } \\
\text { romyces }\end{array}$ & rouxii & $\begin{array}{l}\text { Saccharomyces } \\
\text { rouxii }\end{array}$ & w & punjabi waries, ting \\
\hline $\begin{array}{l}\text { Zygosaccha- } \\
\text { romyces }\end{array}$ & spp. & & & agbelima \\
\hline
\end{tabular}

beer can contribute to human nutrition by the prodution of valuable proteins and amino acids [27]. Phytic acid and polyphenols occur as anti-nutritional factors in cereals such as pearl millet (Pennisetum typhoideum). Fermentations of cooked pearl millet [26] with single cultures of $S$. cerevisiae (reported as $S$. diastaticus) result in slight reductions of these compounds. Added impact can be obtained when mixed or sequential yeast-lactic acid bacteria fermentations are carried out, resulting in an improved protein efficiency ratio and higher digestibility values measured in in-vitro rat feeding studies [25].

Another health-related effect is found in the kombucha or "tea-fungus". The mixed yeastbacterial culture growing on sugary tea extract accumulates lactic $(0.1 \%)$, acetic (traces) and gluconic $(0.01-0.3 \%)$ acids, and some ethanol $(0.3 \%)$. The $\mathrm{pH}$ decreases steadily to about 2.5 [49]. The resulting beverage is considered healthy, and it may be expected that in addition to the acids, some vitamins and minerals will be accumulated.

The antimutagenic activity of milk products fermented by various lactic acid bacteria was enhanced by co-culturing it with Saccharomyces cerevisiae [62]. Since the mechanisms of 
these phenomena are not known, it will be of interest to carry out more research on these functional aspects.

Safety improvement by contributing towards the degradation of potentially toxic naturallyoccurring substances in food ingredients. For instance, cyanogenic glycosides such as amygdalase can be degraded efficiently by $\beta$-glycosidase [EC 3.2.1.21] activities (amygdalase and linamarase) produced by Saccharomycopsis fibuligera [6].

\subsection{Detrimental aspects of yeasts in (fermented) foods}

In particular, oxidative (non-fermenting) yeasts are associated with spoilage of (fermented) foods. Such yeast-associated spoilage can manifest itself as:

Degradation of organic acids, which can be achieved by assimilation or by direct oxidation, causing an increase of $\mathrm{pH}$ and concomitant loss of microbial stability [13].

Formation of yeasty off-odours. In fish paste fermentations, it was found that exclusion of oxygen enabled a better control of undesirable levels of yeast growth and resulting offodours [4]. In tempe, Cryptococcus humicola, Pichia spp. and Rhodotorula minuta were associated with off-odours during the storage of tempe (van Laarhoven, unpubl. observ.). In miso, film-forming yeasts such as Pichia sp. and Zygosaccharomyces rouxii (reported as Z. halomembranis) are detrimental because of their strong unpleasant odour [12].

Formation of discolorations, turbidity and/or gas.

Formation of potentially toxic substances. Ethyl carbamate can accumulate in fermented products undergoing alcoholic fermentation followed by some form of heat treatment. Ethyl carbamate (urethane) is formed by the reaction of carbamic acid with ethanol [11]. Carbamic acid is a yeast metabolite of citrulline. Ethyl carbamate is carcinogenic; the highest levels (100-300 ppb, exceptionally $1 \mathrm{ppm}$ ) are found in distilled alcoholic beverages (brandy, bourbon, sake). In view of the relatively limited consumption of these beverages the risks of ethyl carbamate are considered small.

\subsection{Physiological key properties}

Physiological aspects of importance in the ecology of natural fermentations are the formation of functional enzymes, the assimilation of carbon and nitrogen sources, microbial interactions, tolerance to ethanol and lysis of cells.

Formation of functional enzymes to release assimilable carbon sources. Obviously these enzymes are valuable in brewing and flavour development. For example, glucoamylase (glu- 
can 1,4-alpha-glucosidase) [EC 3.2.1.3] is a key enzyme in rice wine fermentation, converting starch directly into glucose. Glucoamylase from Pseudozyma (= Candida) tsukubaensis was reported to be constitutive and inducible by glucose, starch, maltose and glycerol [59]. Also, $\beta$-glucosidases formed by e.g. Zygosaccharomyces bailii [15] occur as extracellular and intracellular enzymes and can degrade a variety of polysaccharides. This ability would enable the yeast to mobilize assimilable carbon sources. On the other hand, glucosidase activity can also contribute to flavour development as a number of flavour precursors in fruits are glycosides.

Assimilation of wide or narrow ranges of carbon and nitrogen sources that correspond with the nutrients available in natural substrates. Using molecular typing techniques for Saccharomyces cerevisiae, it was observed that in naturally fermenting African maize dough, Saccharomyces cerevisiae strains are involved throughout the fermentation period [20]. The ability to assimilate galactose, saccharose, lactate, raffinose, maltose and glucose was common in these isolates and corresponds very well with the naturally occurring assimilable carbohydrates in uncooked maize. The same group investigated the occurrence of Issatchenkia orientalis [21], which is also a fermentative yeast that contributes to the attractive flavour of maize dough.

Microbial interactions that improve chances for survival and growth. Examples are the proto-cooperative interaction of yeasts and lactic acid bacteria in sourdoughs [38] and the formation of killer-toxins by yeasts that reduce competitive yeasts e. g., in wine fermentations [38].

Tolerance to ethanol, especially related to cytoplasmic membrane composition and of practical importance in alcoholic fermentations that must yield high ( $>15 \% \mathrm{v} / \mathrm{v})$ levels of alcohol content.

Lysis of yeast cells is associated with many of the nutritional benefits but also to enzymatic spoilage phenomena. The lysis is determined by proteases that influence the hydrolysis and solubility of complexes, not involving the cell wall as such [68].

\subsection{Future prospects and conclusions}

The traditional foods mentioned in this chapter are well accepted, affordable and use local resources. It is important to ensure that their quality and safety meet the requirements of present-day and future consumers. Upgrading traditional home-scale processes is needed so that they can compete successfully with imported products. Whereas small-scale manufacture has advantages of short distribution lines, income generation for families etc., urbanization and the resulting growing demand for ready-to-consume foods requires larger-scale industrial production. Examples of industrialized traditional fermented foods are: alcoholic pastes and rice wines in Asia, such as tapai which is now produced at a small cottage scale in Malaysia using commercially available pure culture starters of the starch degrading 
mould Amylomyces rouxii and the yeast Saccharomycopsis fibuligera [31]; palm wine and sorghum beer [16] in S. Africa are prepared at industrial scale in processes involving souring of sorghum mash with Lactobacillus delbrueckii at $48-50{ }^{\circ} \mathrm{C}$. After boiling and straining the obtained wort, alcoholic fermentation is performed at $20-35^{\circ} \mathrm{C}$ using pure strains of Saccharomyces cerevisiae; African doughs such as mawè in Bénin, in which the performance of added starter cultures was tested. Although mawè can be prepared using only lactic acid bacteria such as Lactobacillus brevis, the addition of Issatchenkia orientalis (commonly found in maize dough) enhances the growth of the lactic acid bacteria and the performance of the fermentation [24]. Although it was observed that traditionally fermented dough had a better flavour, added starter cultures can be very useful in semi-industrial settings to achieve predictability of short fermentation times. Mageu, a non-alcoholic sour maize porridge, is produced at an industrial scale in South Africa. A similar product is known in Kenya as uji. Although these porridges are fermented using lactic acid bacteria only, yeasts mainly Pichia spp., as well as Acetobacter liquefaciens are involved in the process as spoilage microorganisms [22]. Spoilage yeasts are kept under control using high fermentation temperatures and chemical preservatives such as benzoate, sorbate and propionate. Ogi, a sour fermented starch cake processed from maize, sorghum or millet grains has been industrialized in Nigeria [47]. The fermentation is not inoculated and depends on the natural fermenting flora in which Lactobacillus plantarum is considered essential. However, yeasts such as Saccharomyces cerevisiae and Pichia fluxuum contribute to the acceptability of the flavour. A cost analysis showed that inoculation with pure culture starters would be unacceptably expensive, considering the infrastructure needed to propagate and maintain appropriate quality and safety of such cultures.

Yeast products such as enzymes, vitamins of the B-group, trace elements (Selenium, Chromium), glycans, flavour components and carotenoid pigments [19] occur in traditional foods, but could be exploited more effectively as purified substances and food ingredients. New processing methods including the use of immobilized yeast cells, are promising for obtaining a higher efficiency of starch degradation and ethanol production in rice wines [57]. The development of starters for commercial processes continues. Miso, a fermented salted paste of soybeans, rice and barley, is produced at a large industrial scale. The fermentation takes place in two stages, a mould solid state fermentation initiated by the inoculation with a koji starter, and a brine fermentation during which halophilic lactic acid bacteria (Tetragenococcus halophila) and yeasts (Zygosaccharomyces rouxii and Candida versatilis) are essential for acidity and flavour development. These are grown as defined mixed cultures and are available commercially for processing [12]. Modern molecular biotechnology for starter culture development resulted in the insertion of the $\alpha$-amylase gene of Saccharomycopsis fibuligera into Saccharomyces cerevisiae [67] with the advantage of more rapid growth and fermentation. Another example is the insertion of a synthetic gene for lysine into Saccharomyces sp. [46]. It was shown that lysine was overproduced and excreted. When used as a fermentation starter culture, the yeast could be used to enrich proteinpoor products such as fufu. However, in view of the cost aspects of industrial production, it is doubtful whether such expensive GMO techniques could be applied in practice. 
In conclusion, a wide variety of yeasts is involved in traditional fermented foods. Those that contribute to desirable product properties require characterization in view of more efficient exploitation, whereas the undesirable yeasts need further study in order to develop consumer-friendly strategies to avoid their metabolic activity.

\subsection{References}

[1] AdAms, M.R.; Nout, M.J.R. (Eds.): Fermentation and Food Safety. Gaithersburg, Md., U.S.A: Aspen Publishers (2001).

[2] Amoa-Awua, W.K.; Frisvad, J.C.; Sefa-Dedeh, S.; Jakobsen, M.: The contribution of moulds and yeasts to the fermentation of agbelima cassava dough. J. Appl. Microbiol. 83 (1997) 288-296.

[3] Armijo, C.; Taboada, J.; Lappe, P.; Ulloa, M.: Products of fermentation by tibicos and associated yeasts. Rev. Latinoam. Microbiol. 33 (1991) 17-23.

[4] AvHuRHI, J.B.; OwENS, J.D.: The influence of oxygen accessibility on the growth of yeast in fish/rice fermentation. J. Fd Sci. Technol. India 27 (1990) 104-106.

[5] BATRA, L.R.: Fermented cereals and grain legumes of India and vicinity. In: Advances in biotechnology. Vol. II. Fuels, chemicals, foods and waste treatment. (edited by Moo-Young, M.; Robinson, C.W.). Toronto, Canada: Pergamon Press (1981) 547-553.

[6] BRIMER, L.; Nout, M.J.R.; Tuncel, G.: Beta-glycosidase (amygdalase and linamarase) from Endomyces fibuliger (LU677): formation and crude enzyme properties. Appl. Microbiol. Biotechnol. 49 (1998) 182-188.

[7] CAmpbell-Platt, G.: Fermented foods of the world. A dictionary and a guide. Guildford, Surrey, UK: Butterworth Scientific (1987).

[8] Chavez, N.A.L.; Wacher Rodarte, M.: The fermentation of pozol: the effect of thermal and alkaline treatment of maize. In: Alimentos fermentados indigenas de Mexico. (edited by Wacher-Rodarte, C.; Lappe, P). Ciudad Universitaria, Mexico D.F., Mexico: Universidad Nacional Autonoma de Mexico (1993) 103-108.

[9] Cronk, T.C.; Steinkraus, K.H.; HaCKLER, L.R.; MATtiCK, L.R.: Indonesian tapé ketan fermentation. Appl. Environ. Microbiol. 33 (1977) 1067-1073.

[10] DemuYakor, B.; OHTA, Y.: Characteristics of single and mixed culture fermentation of pito beer. J. Sci. Fd Agric. 62 (1993) 401-408.

[11] Diachenko, G.W.; CANAS, B.J.; JoE, F.L.; DinOVI, M.: Ethyl carbamate in alcoholic beverages and fermented foods. In: Food safety assessment (edited by Finley, J.W.; Robinson, S.F.; Armstrong, D.J.). ACS Symposium Series No.484, American Chemical Society (1992) 419-428.

[12] EBINE, H.: Industrialization of Japanese miso fermentation. In: Industrialization of indigenous fermented foods (edited by Steinkraus, K.H.). New York, U.S.A.: Marcel Dekker (1989) 89-126.

[13] FlEET, G.: Spoilage yeasts. CRC Crit. Rev. Biotechnol. 12 (1992) 1-44.

[14] Gadaga, T.H.; MutUKUMIRA, A.N.; NARVhUS, J.A.: Enumeration and identification of yeasts isolated from Zimbabwean traditional fermented milk. Intern. Dairy J. 10 (2000) 459-466. 
[15] Gueguen, Y.; Chemardin, P.; Arnaud, A.; Galzy, P.: Comparative study of extracellular and intracellular beta-glucosidases of a new strain of Zygosaccharomyces bailii isolated from fermenting agave juice. J. Appl. Bacteriol. 78 (1995) 270-280.

[16] Haggblade, S.; Holzapfel, W.H.: Industrialization of Africa's indigenous beer brewing. In: Industrialization of indigenous fermented foods (edited by Steinkraus, K.H.). New York, U.S.A.: Marcel Dekker (1989) 191-284.

[17] Halm, M.; Lillie, A.; Sorensen, A.K.; JakobSen, M.: Microbiological and aromatic characteristics of fermented maize doughs for Kenkey production in Ghana. Int. J. Fd Microbiol. 19 (1993) $135-143$.

[18] HARPER, D.B.; Collins, M.A.: Leaf and seed fermentations of western Sudan. In: Applications of biotechnology to traditional fermented foods (edited by Gaden, E.L.; Bokanga, M.; Harlander, S.; Hesseltine, C.W.; Steinkraus, K.H.). Report of an ad-hoc panel of the Board on Science and Technology for International Development. Washington, DC, U.S.A.: National Research Council (1992) 105-113.

[19] HAY, J. D.: Novel yeast products from fermentation processes. J. Chem. Technol. Biotechnol. 58 (1993) 203-205.

[20] HAYFord, A.E.; JeSPERSEN, L.: Characterization of Saccharomyces cerevisiae strains from spontaneously fermented maize dough by profiles of assimilation, chromosome polymorphism, PCR and MAL genotyping. J. Appl. Microbiol. 86 (1999) 284-294.

[21] HAYFORD, A.E.; JAKOBSEN, M.: Characterization of Candida krusei strains from spontaneously fermented maize dough by profiles of assimilation, chromosome profile, polymerase chain reaction and restriction endonuclease analysis. J. Appl. Microbiol. 87 (1999) 29-40.

[22] HolzAPFEL, W.H.: Industrialization of mageu fermentation in South Africa.. In: Industrialization of indigenous fermented foods (edited by Steinkraus, K.H). New York, U.S.A.: Marcel Dekker (1989) 285-328.

[23] Hounhouigan, D.J.; Nout, M.J.R.; NAGo, C.M.; Houben, J.H.; Rombouts, F.M.: Microbiological changes in mawè during natural fermentation. World J. Microbiol. Biotechnol. 10 (1994) 410-413.

[24] Hounhouigan, D.J.; Nout, M.J.R.; NAgo, C.M.; Houben, J.H.; Rombouts, F.M.: Use of starter cultures of lactobacilli and yeast in the fermentation of mawè, an African maize product. Trop. Sci. 39 (1999) 220-226.

[25] Khetarpaul, N.; Chauhan, B.M.: Biological utilisation of pearl millet flour fermented with yeasts and lactobacilli. Pl. Fds Human Nutr. 41 (1991) 309-319.

[26] Khetarpaul, N.; Chauhan, B.M.: Sequential fermentation of pearl millet by yeasts and lactobacilli - effect on the antinutrients and in-vitro digestibility. Pl. Fds Human Nutr. 41 (1991) 321-327.

[27] Konlani, S.; Delgenes, J.P.; Moletta, R.; Traore, A.; DOH, A.: Isolation and physiological characterization of yeasts involved in sorghum beer production. Fd Biotechnol. 10 (1996) 2940 .

[28] LAPPE, P.; UlloA, M.: Microbiology of pulque. In: Alimentos fermentados indigenas de Mexico (edited by Wacher-Rodarte, C.; Lappe, P.). Ciudad Universitaria, Mexico D.F., Mexico: Universidad Nacional Autonoma de Mexico (1993) 75-79.

[29] LEE, C.-H.: Fermentation technology in Korea. Korea University Press (2001).

[30] Lim, G.: Indigenous fermented foods in South East Asia. ASEAN Fd Journ. 6 (1991) 83-101. 
[31] MERICAN, Z.; YeOH, Q.-L.: Tapai processing in Malaysia: a technology in transition. In: Industrialization of indigenous fermented foods (edited by Steinkraus, K.H). New York, U.S.A.: Marcel Dekker (1989) 169-189.

[32] Montanari, G.; Zambonelli, C.; Grazia, L.; Kamesheva, G.K.; Shigaeva, M.K.: Saccharomyces unisporus as the principal alcoholic fermentation microorganism of traditional koumiss. J. Dairy Res. 63 (1996) 327-331.

[33] Morais, P.B.; Rosa, C.A.; LinARdi, V.R.; Pataro, C.; MaiA, A.: Characterization and succession of yeast populations associated with spontaneous fermentations during the production of Brazilian sugar cane Aguardente. World J. Microbiol. Biotechnol. 13 (1997) 241-243.

[34] MPuchane, S.: Fermentation studies on "ting". In: Alternative uses for Sorghum in Botswana, Proc. Workshop. Harare, Zimbabwe; Gaberone, Botswana: Botswana Post Production Food Industry Advisory Unit (1987) 53-73.

[35] NDIR, B.: M'Bannick, acidic fermented milk of Senegal: a microbiological study. In: Development of indigenous fermented foods and food technology in Africa. Proc. IFS/UNU workshop held at Douala, Cameroon Oct 1985 (edited by Prage, L.). IFS provisional report 20 (1991) 398407.

[36] Nout, M.J.R.: Microbiological aspects of the traditional manufacture of Busaa, a Kenyan opaque maize beer. Chem. Mikrobiol. Technol. Lebensmittel 6 (1980) 137-142.

[37] Nout, M.J.R.: Ecological aspects of mixed-culture food fermentations. In: The fungal community: its organization and role in the ecosystem (edited by Carroll, G.C.; Wicklow, D.T.). New York, U.S.A.: Marcel Dekker (1992) 817-851.

[38] Nout, M.J.R.: Fungal interactions in food fermentations. Can. J. Botany 73 (1995) S1291S1300.

[39] Nout, M.J.R.; AIDOO, K.E.: Asian Fungal Fermented Food. In: The mycota, Vol.X: Industrial applications (edited by Osiewacz, H.D.). Berlin, Germany: Springer (2002) 23-47.

[40] NouT, M.J.R.; BARTELT, R.J.: Attraction of a flying nitidulid (Carpophilus humeralis) to volatiles produced by yeasts grown on sweet corn and a corn-based medium. J. Chem. Ecol. 24 (1998) 1217-1239.

[41] Nout, M. J. R.; Rombouts, F. M.: Recent developments in tempe research. J. Appl. Bacteriol. 69 (1990) 609-633.

[42] Nout, M.J.R.; RombouTs, F.M.: Fermented and acidified plant foods. In: The microbiological safety and quality of food (edited by Lund, B.M.; Baird-Parker, T.C.; Gould, G.W.) Gaithersburg, U.S.A.: Aspen Publishers (2000) 685-737.

[43] NOUT, M.J.R.; SARKAR, P.K.: Lactic acid food fermentation in tropical climates. Antonie van Leeuwenhoek 76 (1999) 395-401.

[44] Nout, M.J.R.; De Dreu, M.A.; ZuUrbier, A.M.; BonAnTS-VAn LAARHOVEn, T.M.G.: Ecology of controlled soyabean acidification for tempe manufacture. Fd Microbiol. 4 (1987) 165172.

[45] NuraidA, L.; Wacher, M.C.; Owens, J.D.: Microbiology of pozol, a Mexican fermented maize dough. World J. Microbiol. Biotechnol. 11 (1995) 567-571.

[46] OKafor, N.; OKeKe, B.C.; Umeh, C.; Ibenegbu, C.: Secretion of lysine in a broth medium by lactic bacteria and yeasts associated with garri production using a synthetic gene. Lett. Appl. Microbiol. 28 (1999) 419-422. 
[47] ONYEKWERE, O.O.; AKINRELE, I.A.; KoleOSO, O.A.: Industrialization of ogi fermentation. In: Industrialization of indigenous fermented foods (edited by Steinkraus, K.H.). New York, U.S.A.: Marcel Dekker. (1989) 329-362.

[48] OYEWOLE, O.B.: Characteristics and significance of yeasts involvement in cassava fermentation for fufu production. Int. J. Fd Microbiol. 65 (2001) 213-218.

[49] ReISS, J.: The 'tea fungus' and its metabolic products. Deutsche Lebensmittel-Rundschau 83 (1987) 286-290.

[50] Rombouts, F.M.; Nout, M.J.R.: Microbial fermentation in the production of plant foods. J. Appl. Bacteriol. Symp. Ser. 79 (1995) 108S-117S.

[51] Rubio, T.; LAPPE, P.; WACHER, C.: Microbial and biochemical studies of the fermentation of sugary solutions inoculated with tibi grains. In: Alimentos fermentados indigenas de Mexico (edited by Wacher-Rodarte, C.; Lappe, P.). Ciudad Universitaria, Mexico D.F., Mexico: Universidad Nacional Autonoma de Mexico (1993) 93-101.

[52] SAKaI, H.; CALdo, G.A.: Microbiological studies on bubod, a fermentation starter in the Philippines. II. Isolation and identification of yeasts. Philippine Agricult. 68 (1985) 139-144.

[53] SAKaI, H.; CALdo, G.A.: Microbiological studies on bubod, a fermentation starter in the Philippines. III. A new yeast species, Endomycopsis bubodii Sakai and Caldo sp. nov., and some enzymological properties of Endomycopsis strains. Philippine Agricult. 68 (1985) 181-188.

[54] SANNI, A.I.; OnILUdE, A.A.; FADAhUNSI, I.F.; AfOLABI, R.O.: Microbial deterioration of traditional alcoholic beverages in Nigeria. Fd Res. Int. 32 (1999) 163-167.

[55] SARKAR, P.K.; TAMANG, J.P.; COOK, P.E.; OwENS, J.D.: Kinema - a traditional soybean fermented food: proximate composition and microflora. Fd Microbiol. 11 (1994) 47-55.

[56] Sefa-Dedeh, S.; SANni, A.I.; Tetteh, G.; SAKYi-Dawson, E.: Yeasts in the traditional brewing of pito in Ghana. World J. Microbiol. Biotechnol. 15 (1999) 593-597.

[57] Shindo, S.; KASHIWAGI, Y.; SHIINOKI, S.: Saké brewing from liquefied-rice with immobilised fungal mycelia and immobilised yeast cells. J. Inst. Brew. 104 (1998) 277-281.

[58] SonI, S.K.; SANDHU, D.K.: Role of yeast domination in Indian idli batter fermentation. World J. Microbiol. Biotechnol. 7 (1991) 505-507.

[59] Soon Bai Chun; Hee Young Chung: Induction of glucoamylase in the yeast Candida tsukubaensis. J. Biochem. Molec. Biol. 28 (1995) 342-347.

[60] SteinkRaus, K.H.: Lactic acid fermentations. In: Applications of biotechnology to traditional fermented foods (edited by Gaden, E.L.; Bokanga, M.; Harlander, S.; Hesseltine, C.W.; Steinkraus, K.H.). Report of an ad-hoc panel of the Board on Science and Technology for International Development. Washington, DC, U.S.A..: National Research Council (1992) 43-51.

[61] SteInKRaus, K.H.: Handbook of indigenous fermented foods. New York, U.S.A.: Marcel Dekker (1995).

[62] TAmaI, Y.; Oishi, H.; NAKagawa, I.; Watanabe, Y.; Shinmoto, H.; Kuwabara, Y.; YAMATO, K.; NAGAI, S.: Antimutagenic activity of the milk fermented by mixed-cultured with various lactic acid bacteria and a yeast. J. Jap. Soc. Fd Sci. Technol. - Nippon Shokuhin Kogyo Gakkaishi 42 (1995) 383-387.

[63] TAMANG, J.P.; SARKAR, P.K.: Microflora of murcha: an amylolytic fermentation starter. Microbios 81 (1995) 115-122. 
[64] TEOH, A.; CiX, J.M.; HEARD, G.M.: Yeasts: an essential partner in kombucha fermentation. In: Proc. $19^{\text {th }}$ Int. Spec. Symp.Yeasts: Yeasts in the production and spoilage of food and beverages. Braga, Portugal: Univ. of Minho (1998) 155.

[65] Uzochukwu, S.; Balogh, E.; Tucknot, O.G.; Lewis, M.J.; NGOdDY, P.O.: Role of palm wine yeasts and bacteria in palm wine aroma . J. Fd Sci. Technol. Mysore 36 (1999 ) 301-304.

[66] Venkatasubbaiah, P.; Dwarakanath, C.T.; Sreenivasa Murthy, V.: Involvement of yeast flora in idli batter fermentation. J. Fd Sci. Technol., India 22 (1985) 88-90.

[67] YIP, C.W.; LIEW, C.W.; NGA, B.H.: Ribosomal RNA genes of Endomyces fibuliger: isolation, sequencing and the use of the 26S rRNA gene in integrative transformation of Saccharomyces cerevisiae for efficient expression of the alpha-amylase gene of Endomyces fibuliger. World J. Microbiol. Biotechnol. 13 (1997) 103-117.

[68] Zambonelli, C.; Rainieri, S.; Chiavari, C.; Montanari, G.; Benevelli, M.; GraZia, L.: Autolysis of yeasts and bacteria in fermented foods. Ital. J. Fd Sci. 12 (2000) 9-21. 
